\title{
APLIKASI PEMBUATAN LAPORAN KEUANGAN SEDERHANA DALAM DUNIA USAHA
}

\author{
Asep Suherman, Hestu Nugroho Warasto, Sawukir \\ Program Studi Manajemen \\ Universitas Pamulang \\ dosen02438@unpam.ac.id
}

\begin{abstract}
Community service activities need to be transferred to the knowledge and techniques of making simple financial reports to the Jama'at Al Awwal Mosque in Jakarta so that they can be independent in preparing their financial statements. The method used consists of delivering material and practice / application of making financial statements. Displaying activities before implementing PKM of Al Awwal Jamaat Mosque depok jaya lack of understanding of simple financial statements, but after the implementation of activities familiar with Al Awwal Jamaat depok jaya Mosque is quite mastered and can make simple financial reports. PKM activities indirectly very positive in increasing participant's knowledge and participant's skills in making simple financial statements. The Activity Method is used by moving the Head of the Mosque Management at Al Awwal Mosque, Jalan Mawar Raya Depok Jaya and looking for problems that are in place so as to provide the right solution in motivating business people in Depok, West Java, Al Awwal Mosque, Depok Jaya. After analysis, we provide training in materials and practices in developing simple financial applications for representatives of the Head of the Community Associations at the Jamaah Al Awwal Mosque, Depok Jaya.
\end{abstract}

Keywords: PKM, Application, Reports, Finance, Simple

\begin{abstract}
Abstrak
Kegiatan pegabdian kepada masyarakat ini bertujuan untuk mentransfer pengetahuan dan teknik pembuatan laporan keuangan sederhana pada Jamaah Mesjid Al Awwal depok jaya agar dapat mandiri dalam pembuatan laporan keuangannya. Adapun metode yang dilakukan berupa penyampian materi dan praktik/penerapan pembuatan laporan keuangan. Hasil kegiatan menunjukkan bahwa sebelum pelaksanaan PKM Jamaah Mesjid Al Awwal depok jaya kurang menguasai mengenai laporan keuangan sederhana, namun setelah pelaksaan kegiatan diketahui Jamaah Mesjid Al Awwal depok jaya cukup menguasai dan dapat membuat laporan keuangan
\end{abstract}


sederhana. Kegiatan PKM secara tidak langsung sangat berperan positif dalam meningkatkan pengetahuan peserta dan keterampilan peserta dalam pembuatan laporan keuangan sederhana. Metode kegiatan yang digunakan adalah bekerjasama dengan Kepala Pengurus Mesjid di Masjid Al Awwal Jalan Mawar Raya Depok Jaya dan mencari pemasalahan yang ada di tempat tersebut sehingga dapat memberikan solusi yang tepat dalam memotivasi sebagai pebisnis di Depok Jawa Barat khususnya Jamaah Mesjid Al Awwal Depok Jaya. Setelah di analisis maka kami memberikan pelatihan dalam bentuk materi dan praktek dalam mengembangkan Aplikasi keuangan sederhana untuk kepada para perwakilan Ketua Rukun Warga di Jamaah Mesjid Al Awwal Depok Jaya

Kata Kunci : PKM, Aplikasi, Laporan Keuangan, Sederhana

\section{A. PENDAHULUAN}

UMKM sebagai suatu entity ekonomi didirikan dengan maksud untuk melaksanakan serangkaian aktivitas-aktivtas dan kegiatan-kegiatan yang bersifat ekonomi, dimana diharapkan dapat memperoleh suatu hasil akhir yang menguntungkan bagi pihak-pihak yang berkepentingan atas UMKM tersebut. Hasil akhir aktivitas-aktivitas dan kegiatan UMKM itu tergambar dalam seperangkat laporan yang disusun oleh pihak manajemen itu sendiri. Dalam membuat laporan ini biasanya UMKM menggunakan data-data keuangan, sehingga laporan ini disebut dengan laporan keuangan. Saat ini sudah banyak ditemui perusahaan yang didirikan dengan melakukan serangkaian aktivitas guna pencapaian laba atau keuntungan UMKM, dimana untuk melakukan olah data tersebut ilmu akuntansi memiliki peranan yang sangat penting, baik itu UMKM berskala kecil maupun UMKM berskala besar. Sehingga dengan adanya ilmu akuntansi, penyajian laporan perusahaan dapat menyediakan informasi yang baik, dan dapat pula dipergunakan untuk pihak-pihak yang memerlukannya baik itu pihak intern maupun ekstern.

Dari data pengurus masjid rata-rata Jamaah Mesjid Al Awwal Depok Jaya menjadi wirausaha dan masih kurangnya pengetahuan cara membuat laporan keuangan Melihat kenyataan perlu dan mendesaknya kebutuhan Jamaah Mesjid Al Awwal Depok Jaya akan keterampilan membuat laporan keuangan, maka dirasa perlu adanya pelatihan pembuatan laporan keuangan sedarhana bagi Jamaah Mesjid Al Awwal Depok Jaya guna meningkatkan kompetensi dan pemahaman mengenai tata cara pembuatan laporan sederhana yang pada akhirnya diharapkan Jamaah Masjid Al Awwal Depok Jaya nantinya dapat membuat laporan keuangan mandiri.

\section{B. METODE PELAKSANAAN KEGIATAN}

Metode kegiatan yang digunakan adalah dengan melakukan kunjungan langsung ke Masjid Al Awwal Depok Jaya, dan memberikan pelatihan disana pada tanggal 27 Oktober 2019 sampai dengan 29 Oktober 2019. Langkah awal metode pelaksanaan kegiatan pengabdian ini yaitu penyampain pengetahuan mengenai pembuatan laporan keuangan 
sederhana pada. Kegiatan ini dilakukan dengan tatap muka secara langsung yang disertai diskusi dan tanya jawab mengenai materi yang disampaiakan. Adapun materi yang disampaian mengenai pembuatan laporan keuangan sederhana yang meliputi Neraca, laporan laba rugi dan perubahan modal.

\section{HASIL DAN PEMBAHASAN}

Penerapan pembuatan laporan keuangan sederhana dilakukan dengan memberikan simulasi ke seluruh peserta mengenai cara membuat laporan keuangan sederhana dalam dunia usaha dengan memberikan contoh jika ingin membuka usaha apa saja yang diperlukan sampai dengan cara membuat laporan sederhana seperti laporan laba rugi dan neraca, dan mencatat semua transaksi-transaksi penjualan maupun pembelian. Kegiatan pengabdian kepada masyarakat ini dimulai dengan melakukan analisis situasi dan koordinasi dengan objek pengabdian kepada masyarakat (Jamaah Mesjid Al Awwal Depok Jaya.), yang dilanjutkan dengan kegiatan inti yang meliputi penyampaian materi mengenai Pengetahuan Pembuatan Laporan Keuangan Sederhana yang kemudian diakhiri dengan kegiatan akhir yaitu evaluasi program. Untuk lebih jelasnya, Tahapan kegiatan PKM ini dapat dijelaskan melalui Gambar berikut ini :

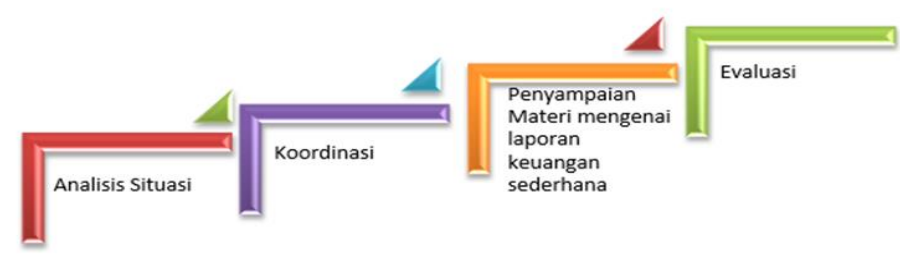

\section{KESIMPULAN DAN SARAN}

\section{Kesimpulan}

Dari hasil kegiatan pengabdian kepada masyarakat di Masjid Al Awwal depok tentang membuat laporan keuangan sederhana dalam dunia usaha dapat ditarik beberapa kesimpulan antara lain sebagai berikut :

1. Pengetahuan peserta dalam hal ini Jamaah Mesjid Al Awwal Depok Jaya mengenai laporan keuangan sederhana sebelum kegiatan PKM mayoritas berada di kategori kurang menguasai.

2. Setelah kegiatan PKM diketahui bahwa pengetahuan peserta mengenai laporan keuangan sederhana setelah disampaikan materi mayoritas berada pada kategori cukup menguasai

3. Terjadi peningkatan pengetahuan dan keterampilan peserta dalam hal pembuatan laporan keuangan sederhana setelah kegiatan ini.

\section{Saran}

Setelah kegiatan pengabdian kepada masyarakat ini berakhir baik dari pelatihan dan pendampingan diharapkan Jamaah Mesjid Al Awwal Depok Jaya,. Khususnya yang mempunyai usaha atau yang baru mau membuka usaha dapat mengaplikasikan laporan 
keuangan sederhana yang di dapat dari pelatihan agar dapat mengetahui kondisi usaha dari laporan keuangan sederhana tersebut.

\section{DAFTAR PUSTAKA}

Horngren \& Harrison, (2005), Akuntansi Di Indonesia, Buku Satu, Salemba Empat, Jakarta.

Firdaus, (2008), Dunia Pengantar Akuntansi Lengkap, Penerbit Salemba Empat, Edisi 3.

Solihin, D. (2019), Pengaruh Current Ratio Dan Debt To Equity Ratio Terhadap Return On Asset (ROA) Pada PT Kalbe Farma, Tbk, KREATIF: Jurnal Ilmiah Prodi Manajemen Universitas Pamulang 7 (1).

Sri W. (2009). Peran UKM Dalam Perekonomian Indonesia, Jurnal Mediargo, Vol. 5, No.1.

Mulyadi. N. (2010), Kewirausahaan \& Manajemen Usaha Kecil, Alfabeta, Bandung,

Febra, R. (2004). Akuntansi Praktis Untuk Usaha Kecil Dan Menengah, Studi Nusa, Semarang. 